\title{
Government ownership and risk taking among European savings banks
}

\author{
Yaseen Ghulam $^{\mathrm{a}, \mathrm{b}}$ and Julian Beier ${ }^{\mathrm{c}}$
}

a. University of Portsmouth, Portsmouth Business School,

Economics and Finance Subject Group

Richmond Building, Portland Street, PO1 3DE, UK

Email: yaseen.ghulam@port.ac.uk

Phone: +442392844127

b. Al Yamamah University 7010 King Fahd Road,

Al Qirawan, Riyadh 13541, Saudi Arabia

c. University of Portsmouth, Portsmouth Business School,

Economics and Finance Subject Group

Richmond Building, Portland Street, PO1 3DE, UK 


\title{
Government Ownership and Risk Taking among European Savings \\ Banks
}

\begin{abstract}
This study aims to investigate whether government ownership of savings banks in Europe has a significant effect on their risk-taking behaviour. The study employs time-varying Zscore to measure risk using yearly accounting and ownership data of 721 savings banks from seven European countries over a period of 16 years from 2000 to 2015, covering the period before, during, and after the global financial crisis. The empirical estimates suggest an overall positive relationship between fully and partly government-owned savings banks and their respective Z-scores. Whereas the same positive relationship was found for the periods before and after the crisis, it could not be confirmed for the crisis period from 2008 to 2010 , indicating that financial shocks render government ownership insignificant in explaining the risk behaviour of savings banks. On a country-level analysis, a positive relationship was obtained for France and Sweden, whereas ownership was not significant for the individual samples of the remaining countries. Overall, government ownership is not associated with an increase in savings banks' risk of default for the crisis period, which therefore contradicts the call for more privatisation within the European banking market.
\end{abstract}

Keywords: Savings banks; Government ownership; Bank risk; Z-score; Time-varying JEL classification: G21 G32 G28 


\section{Introduction}

The relationship between ownership structure and risk-taking behaviour of banks is one of the fundamental research questions within the topic of banking, as evident from the number of studies published over the last decades. By following this trend, this study investigates whether different types of ownership have a significant effect on savings banks' risk-taking behaviour in various European countries, and if so, in which ways this effect is expressed. In general, banks are mutually, privately, or publicly owned. For the latter type, authors such as Ianotta et al. (2013) have found increased risk-taking behaviour compared to private banks as a consequence of the enjoyed governmental protectionism in the form of guarantees, which are said to reduce default risk and create negative incentives. However, a broad picture of the after-crisis integrated European savings banks market as well as a breakdown that allows for a standardised comparison of the influence of ownership in the different countries is yet to be drawn. An understanding of the magnitude of such risk exposure is very important, as state-owned banks hold approximately 21 per cent of the overall banking industry's assets, as shown by Gonzalez-Garcia and Grigoli (2013), who investigated 94 countries, including the major European banking markets in the United Kingdom and Germany.

Within the European Monetary Union, savings banks are of particular interest, as their structures, as well as their ability to absorb systemic shocks, seem to differ fundamentally. This especially became evident over the course of the financial crisis during the years 2008 to 2010 when many banks, including savings banks in Italy, Spain, France, and other European countries, were in need of governmental capital injections in order to continue their operations. In contrast, all of the German Sparkassen, as public institutions, have coped comparably well with the financial crisis and have remained in the hands of the public, 
whereas the Spanish cajas de ahorros were also governmentally influenced but were largely taken over and restructured to become corporations as a result of an immense risk exposure in real estate markets (Cardenas, 2013). Hence, ownership structure may explain risk-taking behaviour of publicly owned institutions if the banking sector is examined as a whole, but this may not necessarily explain the behaviour of individual types of publicly owned banks, which, in the case of savings banks, seem to require a more differentiated analysis.

This study aims to examine and compare the impact of different ownership types on the European savings banks' risk-taking behaviour. This will be measured through a timevarying Z-score, a variable that has gained popularity in the analysis of panel data over the last few years, as it measures the distance to insolvency of individual banks on a rolling basis. The study aims to investigate the risk-taking development of European savings banks from the beginning of the millennium until 2015, encompassing the periods before, during, and after the financial crisis.

The empirical estimates suggest a positive relationship between fully as well as partly government-owned savings banks and their respective Z-scores in the entire sample period. The whole sample was analysed subsequently over three different time frames to capture possible effects of the financial crisis. Whereas the same positive relationship was found for the periods before and after the crisis, it could not be confirmed for the crisis period from 2008 to 2010, indicating that financial shocks render government ownership insignificant in explaining the risk behaviour of savings banks. On a country level, a positive relationship was obtained for France and Sweden, whereas ownership was not significant for the remaining countries. Instead, bank profitability and size were relevant in explaining the Zscore in Germany and Norway, respectively. Overall, government ownership is not 
associated with an increase in savings banks' risk of default, thus questioning the call for more privatisation within the European banking market.

The rest of this study is divided into six sections. Section 2 is devoted to a literature review, which introduces the most relevant research on government ownership and risk taking in the banking industry. In Section 3, the specific methodology employed to answer the research questions is presented and discussed. Section 4 describes the data requirements and sources, whereas Section 5 deals with an in-depth analysis of the regression estimates for the overall sample, different time frames (pre-, mid-, and post-financial crisis), and an analysis of the individual European countries. Section 6 contains the conclusions of the study.

\section{Review of the literature}

The question as to whether different types of ownership influence a bank's risk taking has evolved out of moral hazard and incentive problems arising due to the separation of ownership and control. Berle and Means (1968) and later Jensen and Meckling (1976) recognised that dispersion of ownership can lead to a conflict of objectives. As management equity holdings decrease, they require reduced effort. However, as shareholder concentration increases, increased monitoring activities will decrease discretionary power of management and increase shareholder value. Due to the positive relation between risk and return, this implies riskier investments. This relationship has been empirically found to be significant (Demsetz et al., 1997; Saunders et al., 1990) without definite agreement about the direction.

Agusman et al. (2014) found that, while overall risk did not generally correlate with shareholder concentration, it did so for banks whose government participation increased 
through recapitalisation. Thus, a bank's risk profile may differ depending on whether a majority is held by the public or by private investors. This idea has been subject to numerous studies, evolving around two major perspectives. The first perspective is known as the development view, mainly credited to Gerschenkron (1962), who argued that government participation in the banking industry could be favourable when capital is scarce in order to promote economic growth in the presence of market failures (Gonzalez-Garcia \& Grigoli, 2013) or emerging economies (Ianotta et al., 2013). Amongst others, Stiglitz (1993) states that certain market failures justify government intervention.

A contrasting perspective is the political view, which argues that governments acquire banks as a measure of providing employment or other benefits that assure the government sustained political influence, hence causing inefficiencies. This sceptical view is supported by evidence of inefficient government-owned enterprises (La Porta \& Lopez-de-Silanes, 1999) and has led to the introduction of economic models supporting the privatisation and restructuring of public banks (Shleifer \& Vishny, 1994). In a cross-country study, LaPorta et al. (2002) empirically concluded that government ownership leads to inefficiencies and therefore reduced economic growth in underdeveloped economies with weak property rights. These findings were referred to by Dinç (2005), who put emphasis on the relation between government-owned banks' (GOBs) lending behaviour and election years. He concluded that politicians in emerging economies use their power to increase lending during election years.

Pennathur et al. (2012) analysed the impact of the ownership nature on income diversification and risk of Indian banks. They found that public-sector banks show fewer 
diversified income sources and rely more heavily on traditional loans, increasing overall risk. However, their study failed to control for other factors.

García-Marco and Robles-Fernández (2008) analysed the Spanish banking market using the Z-score as a measure of risk. While commercial banks represent private entities, savings banks represent a fairly unique case, as they are controlled by a large number of stakeholders, mostly public administrations, as well as private investors and firms, making them entities under private and public control. In contrast to Pennathur et al. (2012), they analysed whether differences in risk profiles could also be due to other explanatory variables, such as size. Their results found that size and ownership are significant in explaining risk profiles. While smaller private and public banks presented a lower risk profile, commercial banks were generally more risk-inclined than savings banks (GarcíaGarcía-Marco and Robles-Fernández, 2008). These findings were confirmed by Beck et al. (2009) for Germany.

An earlier study by Fernandez et al. (2006) analysed the impact of savings banks' transition from private to public institutions through the LORCA $^{1}$ law, employing a natural experiment. They concluded that an increase in government participation also led to an increase in the savings banks' risk, but not to an improvement in performance (Fernandez et al., 2006).

\footnotetext{
${ }^{1}$ Ley de regulación de normas básicas sobre órganos rectores de las cajas de ahorros: A 1985 banking law that introduced the percentage representation of public administration, depositors, and employees in the ownership structure and settled the legal and organisational framework of Spanish savings banks in a way that regional and local governments were able to own as much as 51 per cent of a branch, which ultimately classified these as public institutions.
} 
Recently, Ianotta et al. (2013) included electoral cycle data to analyse whether political factors influence the risk-taking behaviour of government-owned banks. Their results showed that government-owned banks exhibit comparatively lower default risk but higher operational risk that rises during the years following elections. Hence, as lower default risk is not explained by superior economic situations, the authors argue it must be due to the government protection that the public banks enjoy, which increase risk-taking incentives (Ianotta et al., 2013).

Government protection exists in the form of deposit insurance, said to create moral hazard problems through decreased market discipline (Ianotta et al., 2013). Since Merton (1977) recognised the cost of deposit insurance and guarantees, a parallel strand of literature focuses on the impact of implicit and explicit guarantees on the risk taking of banks (Keeley, 1990; Cordella \& Yeyati, 2003; Hakenes \& Schnabel, 2010). Gropp et al. (2010) conducted a natural experiment on the discontinuation of government guarantees of German savings banks. Their results showed that banks reduced their credit risk and shifted their funds away from interest-sensitive debt (Gropp et al., 2010).

However, none of the studies mentioned above have analysed the significance of ownership structure on bank risk on a comparative basis for European savings banks covering the period of restructuring during the financial crisis of 2008. Hence, this study fills this gap in the literature by investigating savings banks in seven major European countries in terms of their risk-taking behaviour and the role played by government ownership in increasing/decreasing the appetite for risk. 


\section{Methodology}

This study adds to and extends the existing literature in two ways. First, it covered a time frame (2000 to 2015 ) that, to the best of the author's knowledge, has not been investigated before. Second, by focussing on European savings banks, it became possible to analyse and compare, in terms of ownership structure, a single institutional type that has undergone changes in numerous countries within the observed period.

A panel data pooled regression was conducted in order to test for the effects of ownership structure on savings banks' risk over time. The three regression models were evaluated to follow the assumptions of the classical linear regression model (CLRM) in order to draw correct inferences about the variables' coefficients. These tests were conducted for the whole sample of savings banks as well as for the individual countries. The three main assumptions are that the residuals have a mean of zero $\left(E\left(u_{t}\right)=0\right)$, that the variance of the residuals is constant and smaller than infinity $\left(\operatorname{var}\left(u_{t}\right)=\sigma^{2}<\infty\right)$, and that the residuals are not correlated over time $\left(\operatorname{cov}\left(u_{i}, u_{j}\right)=0\right.$ for $\left.i \neq j\right)($ Brooks, 2014, p. 129). Whereas the first condition is always fulfilled as long as a constant is included in the regression (Brooks, 2014, p. 131), the latter two assumptions needed to be tested. This was done through employing a Durbin-Watson (DW) test that detects autocorrelation between the residuals, as well as a Breusch-Pagan (BP) test searching for heteroscedasticity (non-constant variance) within the error terms. If the assumptions are fulfilled, the OLS method gives the best linear unbiased estimators (BLUE). If the two conditions are not fulfilled, the estimators are still unbiased, but they are no longer the best choice available, as they do not yield the minimum variance property among the class of unbiased estimators (Brooks, 2014, p. 135). If this is the case, other estimation methods, such as the Newey-West estimator, need to be taken into consideration. 
The next step was to identify a variable that accurately measures the default risk of a bank. For major banks, issuer and individual credit ratings, as used by Ianotta et al. (2013), were a reliable proxy for a bank's default risk, as they combine several informative variables, such as asset quality and profitability, into one comprehensive measure. However, as the commonly smaller and regionally operating savings banks are the subject of this study, credit ratings were largely unavailable. An equally meaningful alternative variable to measure default risk is the Z-score. Originally, the Z-score was created by Altman (1968), who employed a multiple discriminant analysis to identify a set of five accounting ratios, which, when combined into a single ratio (Z-score), ought to be able to separate healthy companies from those that will file for bankruptcy. He selected a sample of 66 listed manufacturing companies, 33 of which had filed for bankruptcy during the period from 1946 to 1965 . Indeed, his model was significant in predicting the solvency of the firms: it estimated the correct outcome for 94 per cent of the selected sample. In future academic papers, Altman developed multiple variations of his model that were designed to render it applicable to non-manufacturing and service companies (Vaziri et al., 2012, p. 123). However, none of these are commonly used for financial institutions. In the late $20^{\text {th }}$ century, multiple scholars (see Boyd \& Graham, 1986 and Hannan \& Hanweck, 1988) developed advanced Z-score models, which were designed for analysing the probability of insolvency of financial institutions, thereby filling this gap in the previous literature. These Z-scores are derived as follows: in the banking literature, a state of insolvency occurs when losses $(-\pi)$ surmount equity $(E)$ :

$$
E<-\pi
$$


This is equal to writing:

$$
E+\pi<0
$$

By dividing both sides by the institution's assets $(A)$, the inequality transforms to:

$$
\frac{E}{A}+\frac{\pi}{A}<0
$$

Hence, the insolvency state is expressed in percentage values rather than absolute values, which has the benefit that this can be compared between institutions of different sizes. By substituting the capital asset ratio $(C A R)$ for $\frac{E}{A}$ and the return on assets $(R O A)$ for $\frac{\pi}{A}$, the inequality can be written as:

$$
C A R+R O A<0
$$

It can be shown that, when ROA is a random variable with mean $\mu_{\text {roa }}$ and variance $\sigma_{\text {roa }}^{2}$, the upper bound of the probability of insolvency according to the Bienaymé-Chebyshev inequality can be written as (Boyd \& Graham, 1986, p. 48):

$$
p(R O A \leq C A R) \leq\left[\frac{\left(\mu_{R O A}+C A R\right)}{\sigma_{R O A}}\right]^{-2}=Z^{-2},
$$

in which $\mathrm{Z}$ represents the $\mathrm{Z}$-score and is identical to:

$$
Z \equiv \frac{\left(\mu_{R O A}+C A R\right)}{\sigma_{R O A}}
$$


The Z-score is expressed in standard deviations. Hence, it expresses by how many standard deviations profits can fall below the mean in order for the equity to become negative and cause bankruptcy of the respective institution (Boyd \& Graham, 1986, p. 48). As can be identified in inequality (5), the Z-score is inversely related to the probability of insolvency, meaning that when $\mathrm{Z}$ rises, the probability of insolvency falls, indicating that this institution has become more stable, and vice versa (Köhler, 2012). For this reason, the Z-score is also said to indicate the distance from insolvency. The described Z-score is mostly used for analysing cross-sectional data. For panel data, a variation called the time-varying Z-score has been put forward in the literature (Lepetit \& Strobel, 2013). Because this dissertation analysed an unstructured panel of data, the latter variation of the Z-score was therefore relevant for this study and has been applied to the data sample. It differs from that for crosssectional data (equation (6) only in that the three variables need to be calculated on a rolling basis for the respective time periods:

$$
Z \equiv \frac{C A R_{i, t}+\mu_{R O A_{i}, t}}{\sigma_{R O A_{i}, t}}>0
$$

where $C A R_{i, t}$ is the capital asset ratio of institution $i$ at time $t$ and $R O A_{i, t}$ is the return on assets of the respective firm $i$ at time $t$ (Lepetit \& Strobel, 2013, p. 74). The expected value of the ROA $(\mu)$ and the standard deviation $(\sigma)$ at time $t$ were calculated on a rolling basis with a window width of $n=3$. The window width determines how many values form the basis for the underlying variable. The calculated value was assigned to the most recent year in the time window. As an example, the expected value $(\mu)$ of ROA for the year 2002 was based on the values from 2000 to 2002. Consequently, the years 2000 and 2001 did not exhibit any values, which in this case was negligible due to a general lack of reported data 
for many institutions during this time period. Additionally, this calculation method yields the advantage that the variables for the respective years are based on past data rather than predicted future values, improving the validity of the model.

The Z-score, as the endogenous variable of the regression, was calculated in three different variations. The variable $R O A$ was represented by the return on average assets (ROAA) in all three variations. This is the return on the mean assets a bank held over the course of a year and is thus representative for the entire year, rather than only the balance sheet key date. However, the variable $C A R$ was measured through three different variables: the Tier 1 ratio, the total capital ratio, and the ratio of equity to total assets. Whereas the latter is the original definition of $C A R$, the Tier 1 ratio differs in that it is calculated by dividing a bank's core capital (Tier 1 capital) by its risk-weighted assets. This adjusted ratio is a commonly used measure for assessing a bank's capital strength and therefore has a higher validity than the $C A R$ when calculating the Z-score. However, it suffers from the limitation that it is available for very few bank-year combinations. Hence, $C A R$ is additionally represented by the total capital ratio, as well as by the ratio of equity to total assets, in order to gain further informational content and to check for the robustness of the results when different Z-score measures are employed.

Ownership structure was measured by employing a dummy variable that took on the value of 1 if a government held stakes exceeding 50 per cent of a saving's bank and 0 otherwise. In consideration of the case that a bank was partially owned by its respective country's government, another dummy variable was employed that took on the value of 1 if the share was above 0 per cent but below 50 per cent, and 0 otherwise. Additional variables were included in the regression because there are, as a matter of course, factors other than 
ownership that influence the risk profile of a bank. It was hypothesised that bank size and profitability are also significant in predicting the riskiness of a savings bank. Size of the bank was included in the regression expressed through the logarithmised value of total assets. This is justified by the idea that larger banks tend to have better access to funds and may also enjoy cost efficiency that can boost return on assets (McAllister \& McManus, 1993), which in return influences the Z-score. This variable was transformed logarithmically in order to be able to interpret the coefficients as proportional differences, making them semi-elasticities. Profitability was measured through return on equity (ROE), which, according to general portfolio theory, was expected to show a positive relationship with overall risk (García-Marco and Robles-Fernández, 2008, p. 338). ROE was not transformed, as it already is a relative measure.

The GDP growth rate, the consumer price index (CPI), the unemployment rate, and the central bank base rate of the bank's respective country were included as control variables to filter for macroeconomic effects. Whereas the first three are commonly included in regressions, the central bank rate offers particular importance when analysing banks or savings banks. Generally, there are two ways in which interest rate changes can affect a bank's risk-taking behaviour. The first is called the substitution effect, which states that higher funding costs for banks increase the price of debt-financing instruments, therefore leading banks to decrease their leverage and substitute debt with equity. The other, contradictory, effect states that higher relative funding costs decrease bank profitability and therefore give them an incentive to take on additional risk (Agur \& Demertzis, 2012, p. 3). It is therefore interesting to see which effect has the stronger weighting. 
The three different variations of the Z-score were regressed individually against the abovementioned variables for each of the seven countries over the full observation period. Furthermore, one regression was conducted that included the full sample of European savings banks. As an analysis of all three versions of the Z-score for each country would surpass the scope of this dissertation, one has been chosen to stand representatively for the further analysis of the corresponding country. The decision criterion was based on whether there are sufficient values available for the calculation, as well as the informational value of the variable. If all three outputs give qualitatively similar results concerning the significance of the coefficients and the sign of the estimates, the Tier 1-based Z-score variable will always be favoured, as it provides superior informational value and leads to more realistic estimates.

These approaches were undertaken in order to analyse country-specific attributes and to give a general survey of the savings banks' situation in Europe. Subsequently, the overall sample was split up in three different time frames: one pre-crisis period from 2000 to 2007 , one crisis period from 2008 to 2010 , and one post-crisis period from 2011 to 2015 . The proxy for the start of the crisis period was the bankruptcy of Lehman Brothers on September 15, 2008. The cut-off point was determined in 2010 , when the liquidity problems from banks spread to sovereign governments (Elliot, 2011). Hence, the author recognises that savings banks in Europe were still influenced by the European sovereign debt crisis during the latter period (Popov \& Van Horen, 2014). A special emphasis was put on the interpretation of the ownership dummy variable coefficient. In accordance with economic theory, a positive coefficient would imply that fully or partly government-owned savings banks (dummy variable equal to 1) tend to have higher Z-scores than privately owned institutions, placing them further away from insolvency. In contrast, a negative coefficient would denote the 
inverse relationship, whereas a coefficient not significantly different from zero would imply no relationship at all.

\section{Data description}

The financial and ownership data for the savings banks over the chosen time interval were extracted from BvD (Bureau van Dijk) Bankscope. The Bloomberg database was used to access macroeconomic data of the respective countries. The data sources can be found in more detail in Table 1.

[Insert table 1 about here]

In a first step, the countries of the European Union had to be screened manually due to three reasons. First, savings banks, defined as focussing on savings mobilisation and having a clear regional focus, (Bülbül et al., 2013, p. 2) do not exist in every country of the European Union (e.g., Great Britain). Second, Bankscope did not collect sufficient data for the required variables during the analysed period (2000 to 2015) for some countries. Hence, countries that have only five or fewer banks were eliminated from the search strategy. Third, Bankscope disclosed some weaknesses concerning its ability to correctly categorise different types of banks: when filtering for savings banks, it also includes Volksbanken and Raiffeisenbanken in Germany in the saving banks category; these do have an explicit regional focus but could be better categorised as cooperative banks (Altunbas, Evans, \& Molyneux, 2001, p. 939).

As a result of the screening mentioned above, seven member countries of the European Union, namely Austria, Finland, France, Germany, Norway, Spain, and Sweden, remained in the sample, totalling 721 savings banks. For each of these, two different types of data sets 
were created. The first set produced all of the employed variables for every year for each bank, while the second included the information on bank ownership necessary in order to classify whether the savings banks are publicly, collectively, or privately owned.

To draw a broad picture of the ownership situation and also to fill missing gaps, the BvD independence indicator, as well as the shareholder names, the number of the respective shareholders, and information on domestic and ultimate ownership were included in the search strategy. The BvD independence indicator is a useful tool, as it simplifies the question of ownership by labelling each bank with a letter ranging from A to D and therefore subdividing them into different classes, depending on the degree of ownership. If no ownership data are available, the individual bank is labelled with a U. Table 2 presents the detailed classification given by BvD.

[Insert table 2 about here]

Using the data on ownership, each bank was examined individually to assign the appropriate category. In cases where the $\mathrm{BvD}$ independence indicator and the shareholder information did not provide sufficient information, specific information provided by the respective institution was used in order to identify the ownership structure.

Macroeconomic data (CPI, GDP growth rates, unemployment rates, and central bank rates) for the respective years were obtained from the Bloomberg database. Macroeconomic variables are included in the regression in order to control for country-specific effects, such as economic growth or recessions in the respective countries, and general macroeconomic development, which might foster developments concerning the risk-taking behaviour of savings banks independently from the main variables, such as ownership, size, and 
profitability. Inflation has been argued to be negatively correlated with bank stability (Altig \& Nosal, 2009, p. 281). It is therefore important to include these data so as to not overestimate the regression coefficients because of a co-movement between the endogenous and exogenous variables that is due to outside, uncontrolled-for factors.

\section{Empirical results}

The estimation of regression was performed in two steps. First, we tested for autocorrelation and heteroscedasticity and chose the final appropriate estimation strategy accordingly. Second, the estimated coefficients for the three alternative Z-scores (the ratio of equity to total assets, total capital ratio, Tier 1) were presented, tested for significance levels, and then interpreted. We repeated this exercise for the entire sample, sub-periods, and individual countries accordingly. In accordance with the methodology, the three regression models with the respectively different versions of the Z-score considering the whole sample of 7692 bank-year observations were tested for autocorrelation and heteroskedasticity, as these two are often present in panel data residuals (Pisa, 2008, p. 79).

Autocorrelation was tested through employing a DW test that checks for first-order autocorrelation between an error and its previous lagged value (Brooks, 2014, p. 144). The result showed that the null hypothesis of no autocorrelation was rejected at the $1 \%$ level of significance, therefore resulting in serial autocorrelation of at least order one. These results were robust for all three regression systems. Heteroscedasticity was tested for by employing a BP test. The result showed that the null hypothesis of homoscedastic errors was rejected at the $1 \%$ level of significance. These results were robust over the three different regression systems. The summarised results of the tests are presented in Table 3. 
There are multiple solutions to dealing with heteroscedasticity or autocorrelation separately, such as taking first differences for first-order autocorrelation or using a generalised least squares (GLS) method to eliminate heteroscedastic error terms (Brooks, 2014). However, when both are present in panel data, a common approach is to use heteroscedastic and autocorrelation consistent (HAC) standard errors (SE) as first introduced by Newey and West (1987). This estimation method has the advantage that it implicitly assumes the infringement of the CLRM assumptions, which improves the SE of the regression and therefore the validity of the coefficients. Moreover, it avoids choosing a lag length, as 'the maximum lag length is one less the maximum number of years per firm' (Petersen, 2008). It also has the advantage that it is especially effective for larger samples, such as the one at hand (Bertrand et al., 2004). In order to scale the regression variables to similar sizes and avoid high coefficient estimates and standard errors, the dependent variables (the Z-scores based on the ratio of equity to total assets, total capital ratio, Tier 1), which are relatively large in value compared to the independent variables, were standardised (Albright et al., 2008).

[Insert table 3 about here]

Table 4 shows the coefficient estimates, as well as the corresponding standard errors, $\mathrm{t}$ statistics, and significance levels, for the dependent Z-score (Tier 1). By looking at these estimates, it becomes evident that both government variables are highly significant. When looking at the respective coefficient estimate signs, it can be seen that there is a clear positive relationship between the ownership structure of European savings banks and their risktaking behaviour. Hence, when a savings bank is fully (government ownership > 50\%) or 
partly (government ownership $<50 \%$ ) government-owned, the Z-score is expected to increase, which therefore augments the distance to insolvency.

This supports the findings of Gropp et al. (2011), who concluded that government protection is either insignificant or shows a decreasing effect on banks' risk taking for their respective sample, contradicting the conventional argument that government protection is associated with higher risk taking. Interestingly, this relationship seems to be independent of the size of the institution, as the logarithm of total assets as a proxy for the institution's size is not significant at any conventional level. However, in accordance with García-Marco and Robles-Fernández (2008), profitability of a savings bank, measured through the return on average equity (ROAE), is significant in explaining the variation of the $\mathrm{Z}$-score at the 5\% level. It has a negative coefficient, implying that, as savings banks become more profitable and increase their equity returns, their Z-score decreases, implying that they have invested in riskier assets. The result stands in accordance with portfolio theory arguing that higher risk must be compensated with higher returns.

\section{[Insert table 4 about here]}

Concerning the control variables, GDP growth, as well as unemployment and the central bank rate, are significant at the $10 \%, 5 \%$, and $1 \%$ level of significance, respectively, whereas inflation measured through the CPI does not contribute to the explanation of the Z-score. The central bank rate coefficient is negative, stating that rising interest rates for European savings banks led to a lower Z-score and therefore riskier behaviour. Consequently, the substitution effect as elaborated by Agur and Demertzis (2012) seems to have a weaker effect on European savings banks than the risk-taking incentive. 
Table 5 presents the same output, but for the Z-score calculated with the total capital ratio and the ratio of equity to total assets. The results are similar to those found in Table 4, as both government variables, as well as ROAE as a measure of profitability, are significant. Differences include that the logarithm of total assets as a measure for size and inflation as a control variable are significant in the regression, for which the Z-score was calculated employing the ratio of equity to total assets. The coefficient estimate of the logarithm of total assets has a negative sign, therefore supporting the theory of McAllister and McManus (1993) that larger banks have better access to funds and invest in riskier investments that can boost returns.

In contrast, the inflation rate coefficient has a positive sign, contradicting Altig and Nosal (2009), who found that rising inflation is expected to decrease bank stability. This could be due to the fact that, especially in the later time frame of the sample period, numerous European states had to deal with deflation, a situation in which a slight inflation would have added to the stability of the banking system. The only difference of the total capital ratio regression is that GDP growth rate is not significant as a control variable.

[Insert table 5 about here]

Time frame analysis for the whole sample and country-level analysis

As the results do not significantly differ across the three alternative variations, two of the Zscore variations were dropped for the subsequent analysis, and the regression coefficients test based on the Tier 1 ratio was chosen as a preferred model. We divided the overall sample period into three sub-samples and again tested for autocorrelation and heteroscedasticity to determine whether the Newey-West estimation method had to be applied. Based on these tests, the regressions, as found in Table 6, were performed. 
It can be noticed that both government ownership variables show a positive coefficient and are significant at the 5\% level for the first and last period but become insignificant for the financial crisis period. The financial crisis period thus contradicts the previous findings. Not only the government ownership variable, but all other variables fail to explain the development of the Z-score during these three years. Hence, it seems that the financial shocks that European savings banks had to suffer cannot be expressed through simple accounting ratios. Additionally, the insignificance of government ownership supports the observation made after the financial crisis that not all entities of the different countries were influenced in similar ways. Hence, these results imply that, whereas the relationship between government ownership and Z-score is robust for a normal condition of the savings banks market, it seems to break down when the market is distressed by a financial shock.

[Insert table 6 about here]

In the following, we present the regression results in Table 7 for six different major individual European countries (Austria, France, Germany, Norway, Spain, and Sweden). Finland was not evaluated individually, as the sample size was too small to produce meaningful estimates and their interpretations. If autocorrelation or heteroscedasticity was detected, the Newey-West estimation was applied to the sample.

Starting with the Austrian savings banks (Sparkassen), it is important to note that the inflation rate variable was omitted from the regression because it showed signs of pairwise correlation with the central bank variable, causing collinearity in the data. The government ownership variable is not significant at any statistical level. This means that bank default risk in Austria is not correlated with the participation of the government in savings banks. 
As will be shown later on, ownership is also not a deciding factor of riskiness in German savings banks, which is intuitive as they are almost identical in structure and organisation. However, two of the control variables contribute to the explanation of the Z-score. The GDP growth rate is significant at the 5\% level, and the central bank rate is highly significant at the $1 \%$ level.

\section{[Insert table 7 about here]}

Similarly, for 40 French savings banks (Caisses d'Epargne), both government ownership variables are significant in explaining the variation in the $\mathrm{Z}$-score at the $1 \%$ and $5 \%$ level, respectively. As both coefficients have a positive sign, French GOBs tend to be associated with higher Z-scores, therefore locating them further away from insolvency. This stands in accordance with the findings of the overall regression. The Z-score is also explained by the institution's size. The coefficient is negative, implying that larger banks are associated with lower Z-scores and more risk taking. This confirms the theory that banks, which are sufficiently large, assume an indirect government protection due to their systemic importance ('too big to fail').

The respective results for the 356 German savings banks (Sparkassen) show that the estimates suggest no significant relationship between bank ownership and savings banks' risk taking. On the one hand, this contradicts the general belief of a moral hazard effect of government guarantees. On the other hand, it also contradicts empirical findings by Gropp et al. (2010), who found a reverse relationship upon the removal of public guarantees. However, it is important to note that ownership structure in general does not influence banks' exposure to risk. It is the resulting change in operations that causes banks to shift their risk profiles. Hence, a non-significant relationship is not surprising in the context of 
the recent financial crisis, during which German savings banks have performed better than their European counterparts.

It can be argued that this is a result of the relatively unchanged operational structure, as German savings banks have maintained their traditional dual role of taking deposits and making loans and have not followed the stream of financial innovations. Hence, their conservative, old-fashioned style of banking is perceived as a very positive feature (Ayadi et al., 2009), which, for this sample, is not associated with ownership structure. Instead, other variables determine the level of riskiness of the respective savings bank, such as profitability, which is highly significant at the $1 \%$ level and suggests a negative relationship between returns and the $\mathrm{Z}$-score. This implies a positive relationship between probability of default and returns, which stands in accordance with the results for the overall sample and portfolio theory.

For Norway's 114 savings banks (Sparebanken), similar to the German sample, full government ownership is not significant in explaining the Z-score. A possible explanation is that government ownership for Norwegian savings banks plays a subordinate role, as they were originally organised as independent institutions with a strong position in the deposits market (Hyttnes, 2010). However, as for France, size is highly significant and indicates lower Z-scores for larger savings banks. Similarly, the results for the 33 Spanish savings banks (Cajas de Ahorros) show that none of the coefficients is significant in explaining the variation in the Z-score. This could be due to two issues. First, due to consolidation in the Spanish savings bank sector, the number of banks available for analysis has decreased dramatically. Second, there were a lot of missing data for the relevant variables so that only a limited number of Z-scores could be calculated. Nonetheless, it can be seen that the first 
government ownership variable (government ownership > 50\%) shows the smallest p-value and, as in all other countries, has a positive coefficient, therefore supporting the view that government-owned banks tend to operate further away from insolvency.

Last, the results in Table 7 for the 60 Swedish savings banks, also called Sparebanken, show that the government ownership variable is significant at the 5\% level and has a positive coefficient. Even though the dependent variable was scaled, rendering it difficult to draw inferences about the magnitude of the effect, it can still be inferred that the effect is strong, as the coefficient estimate (2.5137) is the largest of all the countries analysed. Consequently, Swedish government-owned savings banks operate in a less risky manner than their private counterparts. Additionally, the Z-score is also explained by the logarithm of total assets (significant at the 5\% level) and ROAE (significant at the $10 \%$ level).

\section{Conclusion}

Whereas the theoretical literature argues that the guarantees of government-owned banks create incentives for banks to increase riskiness, the empirical literature has come to varying conclusions. Although the call for privatisation holds a prominent position in the discussion on regulatory strategies after the recent financial crisis, the magnitude of the crisis impact on European savings banks seems unrelated to their ownership structure. This ambiguity was the motivation for this study. Because of their importance in the European Union and the varying success in dealing with the recent financial crisis, the impact of different ownership types on the risk-taking behaviour of European savings banks was investigated and the individual major countries compared. 
Employing a pooled regression with Newey-West estimators to account for autocorrelation and heteroscedasticity, data from 721 savings banks in seven European countries were analysed over the period 2000 to 2015. As a measure of risk, three different Z-scores were regressed against various exogenous variables, including a proxy for size and profitability, as well as dummy variables to account for the extent of governmental ownership and a set of control variables. In the light of the analysis carried out, the empirical estimates suggested a positive relationship between fully as well as partly government-owned savings banks and their respective Z-scores in the whole sample. The results are robust for all three variations. These findings contradict the general theory of moral hazard, but support the conclusions drawn by Ianotta et al. (2013), that GOBs have a lower default risk. On a country-level analysis, the same positive relationship was obtained for France and Sweden, whereas ownership was not significant for the individual sample of the remaining countries. Instead, bank profitability and size were relevant in explaining the Z-score in Germany and Norway, respectively.

One significant implication of the above-mentioned regression results is the absence of a statistically significant relation between government ownership and European savings banks' risk-taking behaviour during the financial crisis period compared with the normal period. Nationalised banks were supposed to take less risk during the crisis period in particular. Hence, the finding for the normal period is in line with the theory but is in fact opposite to the stated aim of state ownership for the crisis period. The banks in some countries were nationalised to reduce the risk appetite of private sector bank managers. A simple review of the literature on the benefits and costs of public ownership also shows some clear benefits of state ownership. For example, publicly owned banks' behaviour in difficult economic conditions could be calmer and more appropriate. In particular, their 
lending policy could be changed within a short period of time to reflect the prevailing market conditions due to the fact that the government has a significant and in some cases countrywide administrative network.

Similarly, some authors believe that lending under public ownership would be according to the needs of the economy, not the needs of the banks. In a situation in which the economy is struggling, nationalised banks would be reluctant to take more risk, because they would find it much harder to turn to a source (the government) for help in difficult times than in a scenario of normal times. Another point worth mentioning is the fact that struggling publicly owned banks can be funded more quickly with larger capital under public ownership due to the possession of administrative control over a longer time period, thus encouraging banks to avoid risky business models. This would help in rebuilding the struggling banks' infrastructure alongside ensuring closer regulation in future to avoid further bank failure. Furthermore, for public sector banks, high returns, particularly during a financial crisis and under difficult economic circumstances, are not a top priority; hence, in this case they are less likely to take excessive risk.

Similarly, banks were nationalised to avoid a series of defaults by ensuring solvency besides filling the gaps in the kinds of credit provided by private banks and thus improving the allocation of resources through directed lending in some countries. State ownership is also expected to ensure higher competition levels, provide effective checks on monopoly powers, and stimulate growth due to the increase in credit availability. Balanced regional development and the augmentation of employment are also further justifications for the state ownership of banks. Despite the fact that we do not observe a clear relation between risk taking and government ownership, in particular during the crisis period, however, at least 
bank managers did not increase the risk during this period. Hence, the case for the privatisation of these banks would still be debatable.

Our employed methodology has three limitations. First, the data set used for the savings banks sample is based on yearly data rather than higher frequency data. As a consequence, the time gaps between the reported data are relatively large, which may lead to the negligence of intra-year effects. Second, the Z-score as a measure of default risk has the drawback that it is partly based on past asset returns, which may cause a misrepresentation of the actual solvency situation of the banks. This problem was partly solved using a more dynamic, time-varying Z-score, for which standard deviation and mean of the returns were calculated on a rolling basis, using a window width of three years. A small window width has the advantage that it considers fewer past values, thus basing the analysis on a more recent representation of the bank's solvency situation. However, this comes with the cost that outliers have a bigger impact on the calculated Z-score. Therefore, when using a bigger window width, this outlier impact becomes smaller, but at the same time more past values are employed. Third, the Z-score is a measure to draw conclusions on an individual institution's distance to insolvency, i.e., its default risk. It is, however, not possible to state any implications about the economic reasons behind the circumstances of individual institutions, i.e., the causes behind their operational business, because of the characteristics of the underlying data.

Nonetheless, the inferences that can be made from these results are of relevance for future discussions on public banking, especially in light of the recent call for more privatisation within the European banking sector. Government ownership is not associated with an increase in savings banks' risk of default, as GOBs tend to have higher Z-scores in the 
underlying sample. Thus, this is clearly a counterargument for privatisation, also keeping in mind that many private savings banks in Europe had to be supported by government funds during the financial crisis. However, the empirical results also show that for some countries the distance to insolvency correlates with the institution's size. This can be seen as an argument for regulators to closely monitor and potentially privatise large GOBs.

The methodological limitations mentioned above give prospect for future research. As the proposed variable to measure default risk has some drawbacks, measures that even more accurately reflect a bank's solvency situation could be employed. One possible alternative is credit ratings that overcome the problems of accounting ratios and are seen as very accurate relative risk measures. However, these are usually not accessible for savings banks, which is largely due to the fact that savings banks are rarely listed on stock exchanges. Hence, the construction of a credit rating system solely for savings banks could be of essential use to deduct more accurate and reliable empirical results.

\section{References}

Abdi, H. (2007) The method of least squares. In N. Salkind (Ed.) Encyclopaedia of Measurement and Statistics (530-532) Thousand Oaks, CA: Sage.

Agur, I. and Demertzis, M. (2012) Excessive Bank Risk Taking and Monetary Policy, (Working Paper (1457/August 2012) Frankfurt am Main: ECB.

Agusman, A., Cullen, A. S., Gasbarro, D., Monroe, G. S. and Zumwalt, K. J. (2014) Government intervention, bank ownership and risk-taking during the Indonesian financial crisis, Pacific-Basin Finance Journal 30: 114-131.

Albright, S., Winston, W. and Zappe, C. (2008) Data Analysis and Decision Making with Microsoft Excel, Revised. Mason, OH: Cengage Learning. 
Altig, D. E. and Nosal, E. (2009) Monetary Policy in Low-Inflation Economies. New York: CUP.

Altman, E. I. (1968) Financial ratios, discriminant analysis and the prediction of corporate bankruptcy. The Journal of Finance 23(4): 589-609.

Altunbas, Y., Evans, L. and Molyneux, P. (2001) Bank ownership and efficiency. Journal of Money, Credit and Banking 33(4): 926-954.

Ayadi, R., Schmidt, R. H. and Valverde, S. C. (2009) Investigating Diversity in the Banking Sector in Europe, (Report) Brussels: Center for European Policy Studies.

Beck, T., Hesse, H., Kick, T. and von Westerhagen, N. (2009) Bank ownership and stability: evidence from Germany, Unpublished article.

Berle, A. A., and Means, G C. (1968) The Modern Corporation and Private Property. (Rev. ed.) New York, NY: Harcourt, Brace and World.

Bertrand, M., Duflo, E. and Mullainathan, S. (2004) How much should we trust differencesin-differences estimates? Quarterly Journal of Economics 119(1): 249-275.

Boyd, J. H., Graham,S. L. (1986) Risk, Regulation, and Bank Holding Company Expansion into Nonbanking, (Quarterly Review 10) Minneapolis: Federal Reserve Bank of Minneapolis.

Brooks, C. (2014): Introductory Econometrics for Finance (3rd ed.) Cambridge: CUP.

Bülbül, D., Schmidt, R. H. and Schüwer, U. (2013) Savings Banks and Cooperative Banks in Europe', (White Paper Series (5) Frankfurt am Main: Sustainable Architecture for Finance in Europe (SAFE)

Cardenas, A. (2013) The Spanish Savings Bank Crisis: History, Causes and Responses, (IN3 Working Paper Series WP13-003) Barcelona, Universitat Oberta de Catalunya. Available at: $\quad$ http://elcrps.uoc.edu/index.php/in3-working-paper-series/article/view/1943/n13cardenas 
Cordella, T. and Yeyati, E. L. (2003) Bank bailouts: moral hazard vs. value effect. Journal of Financial Intermediation 12(4): 300-330.

Demsetz, R. S., Saidenberg, M. R. and Strahan, P. E. (1997) Agency Problems and Risk Taking at Banks, (Staff Reports, (29) New York: FED.

Dinc, I. S. (2005) Politicians and banks: political influences on government-owned banks in emerging markets. Journal of Financial Economics 77(2): 453-479.

Fernández, A. I., Fonseca, A. R. and González, F. (2006) The effect of government ownership on bank profitability and risk: the Spanish experiment. In Severov, G. P. (Ed.) International finance and monetary policy (209-228) New York: Nova Science.

García-Marco, T. and Robles-Fernández, D. M. (2008) Risk-taking behaviour and ownership in the banking industry: The Spanish evidence. Journal of Economics and Business 60(4): 332-354.

Elliot, L. (2011, August 7) Global financial crisis: five key stages 2007-2011. The Guardian. Greschenkron, A. (1962) Economic Backwardness in Historical Perspective. A Book of Essays. Cambridge, Massachusetts: Belknap Press of Harvard University Press.

Gonzalez-Garcia, J. and Grigoli, F. (2013) State Owned Banks and Fiscal Discipline, (IMF Working paper 13/206)

Gropp, R., Gruendl, C. and Guettler, A. (2010) The Impact of Public Guarantees on Bank Risk Taking-Evidence from a Natural Experiment, (ECB Working Paper No 1272) Frankfurt: European Central Bank.

Gropp, R., Hakenes, H. and Schnabel, I. (2011) Competition, risk-shifting, and public bailout policies. The Review of Financial Studies 24(6): 2084-2120.

Hakenes, H. and Schnabel, I. (2010) Banks without parachutes: Competitive effects of government bail-out policies. Journal of Financial Stability 6(3): 156-168. 
Hannan, T. H. and Hanweck, G. A. (1988) Bank insolvency risk and the market for large certificates of deposit. Journal of Money, Credit and Banking 20(2): 203-211.

Hyttnes, A. (2010) The Norwegian economy, savings bank sector and the equity certificates (EC) available at: http://www.sparebankforeningen.no/id/14549.0.

Ianotta, G., Nocera, G. and Sironi, A. (2013) The impact of government ownership on bank risk. Journal of Financial Intermediation 22(2): 152-176.

Jensen, C. M. and Meckling, H. M. (1976) Theory of the firm: Managerial behaviour, agency costs and ownership structure. Journal of Financial Economics 3(4): 305-360.

Keeley, M. C. (1990) Deposit insurance, risk and market power in banking. The American Economic Review 80(5): 1183-2000.

Köhler, M. (2012) Which Banks are More Risky? The Impact of Loan Growth and Business Model on Bank Risk-Taking, (Discussion Paper No 33/2012) Frankfurt am Main: Deutsche Bundesbank.

Laeven, L. and Levine, R. (2009) Bank governance, regulation and risk taking. Journal of Financial Economics 93 (2): 259-275.

La Porta, R. and Lopez-de-Silanes, F. (1999) The benefits of privatization: Evidence from Mexico. Quarterly Journal of Economics 114(4): 1193-1242.

La Porta, R., Lopez-de-Silanes, F. and Shleifer, A. (2002) Government ownership of banks. The Journal of Finance 57(1): 265-301.

Lepetit, L. and Strobel, F. (2013) Bank insolvency risk and time-varying Z-score measures. Journal of International Financial Markets, Institutions and Money 25: 73-87.

McAllister, P. H. and McMannus, D. (1993) Resolving the scale efficiency puzzle in banking. Journal of Banking and Finance 17(2-3): 389-405.

Merton, R. C. (1977) An analytic derivation of the cost of deposit insurance and loan guarantees. Journal of Banking and Finance 1(1): 3-11. 
Newey, W. K., and West, K. (1987) A Simple, positive semi-definite, heteroskedasticity and autocorrelation consistent covariance matrix. Econometrica 55(3): 703-708.

Pisa, A. M. (2008) Explaining competitive currencies: domestic politics, international trade, and exchange rate valuation. San Diego: ProQuest.

Pennathur, A. K., Subrahmanyam, V. and Vishwasrao, S. (2012) Income diversification and risk: Does ownership matter? An empirical examination of Indian banks. Journal of Banking and Finance 36(8): 2203-2215.

Petersen, M. A. (2008) Estimating standard errors in finance panel data sets: Comparing approaches. The Review of Financial Studies 22(1): 435-480.

Popov, A. and Van Horen, N. (2014) Exporting sovereign stress: evidence from syndicated bank lending during the euro area sovereign debt crisis. Review of Finance 19 (5): 18251866.

Saunders, A., Strock, E. and Travlos N. G. (1990) Ownership structure, deregulation, and bank risk taking. Journal of Finance 45(2): 643-654.

Shleifer, A. and Vishny, R. W. (1994) Politicians and firms. Quarterly Journal of Economics 109(4): 995-1025.

Stiglitz, J. E. (1993) The role of the state in financial markets. The World Bank Economic Review, 7(suppl 1), 19-52.

Vaziri, M., Bhuyan, R. and Manuel, P. A. V. (2012) Comparative predictability of failure of financial institutions using multiple models. Investment Management and Financial Innovations 9(2): 120-127. 
Table 1: Construction of variables and data sources

\begin{tabular}{lll}
\hline Series & Description & Source \\
\hline Total assets & All positions on active side of the balance sheet summed up & Bankscope \\
ROAE & Net profits divided by total average asset & Bankscope \\
Tier 1 ratio & Net profits divided by total average equity & Bankscope \\
& $\begin{array}{l}\text { Core equity capital divided by total risk weighted assets. } \\
\text { Core equity capital (Tier 1 capital) is the banks common }\end{array}$ & Bankscope \\
& $\begin{array}{l}\text { stock plus disclosed reserves. Risk weighted assets are the } \\
\text { bank's assets weighted with the respective credit risk }\end{array}$ & \\
Total capital ratio & Tier 1 capital + Tier 2 capital divided by the banks risk & Bankscope \\
Equity/ total assets & Theighted assets. & \\
Real GDP growth & Annual GDP growth rate adjusted for inflation. \\
CPI & $\begin{array}{l}\text { Consumer price index considers the weighted average of a } \\
\text { basket of consumer goods weighted according to their }\end{array}$ & Bloomberg \\
& $\begin{array}{l}\text { importance. } \\
\text { Harmonised unemployment rate = number of unemployed }\end{array}$ & Bloomberg \\
Unemployment & $\begin{array}{l}\text { people as a percentage of total labour force. } \\
\text { rate }\end{array}$ & $\begin{array}{l}\text { Interest rate that a county's central bank can charge when } \\
\text { lending money to domestic banks }\end{array}$ \\
\hline
\end{tabular}


Table 2: BvD independence indicator classification (BvD Bankscope, 2015)

\begin{tabular}{|c|c|}
\hline $\mathrm{A}+$ & \multirow{3}{*}{$\begin{array}{l}\text { No shareholder with more than } 25 \% \text { of direct or total ownership } \\
\text { (= independent companies) }\end{array}$} \\
\hline $\mathrm{A}$ & \\
\hline A- & \\
\hline $\mathrm{B}+$ & \multirow{3}{*}{$\begin{array}{l}\text { No shareholder recorded with more than } 50 \% \text { of direct, indirect or total ownership } \\
\text { One or more shareholders recorded with more than } 25 \% \text { of direct or total ownership }\end{array}$} \\
\hline B & \\
\hline B- & \\
\hline $\mathrm{C}+$ & \multirow{2}{*}{$\begin{array}{l}\text { No shareholder recorded with more than } 50 \% \text { of direct ownership } \\
\text { One shareholder recorded with more than } 50 \% \text { of total ownership } \\
\text { (= indirectly majority owned) }\end{array}$} \\
\hline $\mathrm{C}$ & \\
\hline $\mathrm{D}$ & $\begin{array}{l}\text { One shareholder recorded with more than } 50 \% \text { of direct ownership } \\
\text { (= directly majority owned) }\end{array}$ \\
\hline $\mathrm{U}$ & Unknown \\
\hline
\end{tabular}


Table 3: Durbin-Watson and Breusch-Pagan test for the whole sample of savings banks

\begin{tabular}{clrrr}
\hline Dependent Variable & Test & Test statistic & p-value & Degrees of freedom \\
\hline \multirow{2}{*}{ Equity } & Durbin-Watson & 0.9388 & 0.0000 & $/$ \\
${ } }$ & Breusch-Pagan & 59.7260 & 0.0000 & 8 \\
\hline \multirow{2}{*}{ Total capital ratio } & Durbin-Watson & 1.0044 & 0.0000 & $/$ \\
& Breusch-Pagan & 30.1520 & 0.0002 & 8 \\
\hline \multirow{2}{*}{ Tier 1 } & Durbin-Watson & 1.4607 & 0.0000 & $/$ \\
& Breusch-Pagan & 25.4290 & 0.0013 & 8 \\
\hline
\end{tabular}


Table 4: Coefficient test for the whole sample (Tier 1)

\begin{tabular}{lcccc}
\hline Variable & Estimate & SE & T-Value & P-value \\
\hline Intercept & 0.3104 & 0.1572 & 1.9750 & $0.0484 * *$ \\
Total assets & -0.0131 & 0.0082 & -1.5835 & 0.1135 \\
ROAE & -0.0007 & 0.0003 & -2.2799 & $0.0227 * *$ \\
Government $>50 \%$ & 0.1649 & 0.0585 & 2.8188 & $0.0049 * * *$ \\
Government $<50 \%$ & 0.2386 & 0.0784 & 3.0442 & $0.0024 * * *$ \\
GDP growth rate & 1.0836 & 0.5244 & 2.0665 & $0.0389 * *$ \\
Unemployment rate & -1.3013 & 0.5492 & -2.3693 & $0.0179 * *$ \\
Inflation rate & -2.6321 & 2.6301 & -1.0008 & 0.3171 \\
Central bank rate & -4.2709 & 1.2900 & -3.3109 & $0.0009 * *$ \\
\hline $\mathrm{R}^{2}$ & 0.0210 & & & \\
$\mathrm{R}^{2}$ adjusted & 0.0172 & & & \\
\hline
\end{tabular}

Notes: $* * *, * *$ and $*$ denote significance at the $1 \%, 5 \%$ and $10 \%$ level, respectively. 
Table 5: Coefficient test for the whole sample (alternative definition of risk)

\begin{tabular}{|c|c|c|c|c|}
\hline \multirow[b]{2}{*}{ Variable } & \multicolumn{2}{|c|}{ total capital ratio } & \multicolumn{2}{|c|}{ equity/total assets } \\
\hline & Estimate & SE & Estimate & $\mathrm{SE}$ \\
\hline Intercept & $0.3513 *$ & 0.2024 & 0.2530 & 0.1565 \\
\hline Total assets & -0.0164 & 0.0107 & $-0.0148 *$ & 0.0075 \\
\hline ROAE & $-0.0008 * *$ & 0.0004 & $-0.0007 *$ & 0.0004 \\
\hline Government $>50 \%$ & $0.1249 * * *$ & 0.0428 & $0.1117 * * *$ & 0.0391 \\
\hline Government $<50 \%$ & $0.2309 * * *$ & 0.0783 & $0.0830 * *$ & 0.0332 \\
\hline GDP growth rate & 0.6291 & 0.4379 & $1.6647 * * *$ & 0.5736 \\
\hline Unemployment rate & $-1.2903 * *$ & 0.5955 & $-0.4764 * *$ & 0.2231 \\
\hline Inflation rate & -0.6407 & 2.1054 & $3.5254 * *$ & 1.7284 \\
\hline Central bank rate & $-4.2261 * * *$ & 1.5640 & $-6.8847 * * *$ & 2.2121 \\
\hline $\mathrm{R}^{2}$ & 0.0152 & & 0.0125 & \\
\hline $\mathrm{R}^{2}$ adjusted & 0.0127 & & 0.0123 & \\
\hline
\end{tabular}

Notes: $* * *, * *$ and $*$ denote significance at the $1 \%, 5 \%$ and $10 \%$ level, respectively. 
Table 6: Coefficient test for whole sample (Tier 1)

\begin{tabular}{|c|c|c|c|c|c|c|}
\hline \multirow[b]{2}{*}{ Variable } & \multicolumn{2}{|c|}{$2000-2007$} & \multicolumn{2}{|c|}{$2008-2010$} & \multicolumn{2}{|c|}{$2011-2015$} \\
\hline & Estimate & $\mathrm{SE}$ & Estimate & SE & Estimate & SE \\
\hline Intercept & $2.1383^{*}$ & 1.1935 & 0.0407 & 0.4739 & 0.2899 & 0.2094 \\
\hline Total assets & $-0.1223^{*}$ & 0.0630 & 0.0073 & 0.0263 & -0.0140 & 0.0116 \\
\hline ROAE & $0.0097^{*}$ & 0.0056 & -0.0064 & 0.0099 & $-0.0005^{*}$ & 0.0002 \\
\hline Government $>50 \%$ & $0.8990 * *$ & 0.3915 & 0.1603 & 0.2068 & $0.1345^{*}$ & 0.0769 \\
\hline Government $<50 \%$ & $0.6824 *$ & 0.3791 & 0.2125 & 0.4240 & $0.1391 *$ & 0.0841 \\
\hline GDP growth rate & -0.0030 & 0.0053 & 0.0331 & 0.0212 & 0.0025 & 0.0144 \\
\hline Unemployment rate & -0.0095 & 0.0254 & -0.0172 & 0.0281 & -0.0053 & 0.0051 \\
\hline Inflation rate & -0.0166 & 0.0231 & -0.0071 & 0.0861 & $-0.0505 *$ & 0.0266 \\
\hline Central bank rate & 0.0337 & 0.0281 & -0.0453 & 0.0820 & $-0.0467 *$ & 0.0266 \\
\hline
\end{tabular}

Notes: $* * * * *$ and $*$ denote significance at the $1 \%, 5 \%$ and $10 \%$ level, respectively. 
Table 7: Coefficient Test for the Z-Score Based on the Equity to Total Assets Ratio

\begin{tabular}{|c|c|c|c|c|c|c|c|}
\hline Variable & & Austria & France & Germany & Norway & Spain & Sweden \\
\hline \multirow[t]{2}{*}{ Intercept } & Coef. & -0.4556 & 2.3970 & $1.3057 * *$ & 3.6308 & -0.7948 & 1.7805 \\
\hline & SE & 1.7616 & 2.3256 & 0.6376 & 2.4193 & 2.4511 & 1.1144 \\
\hline \multirow[t]{2}{*}{ Total assets } & Coef. & 0.0445 & $-0.1431 * * *$ & -0.0263 & $-0.0666^{* *}$ & -0.0284 & $-0.0892 * *$ \\
\hline & SE & 0.0566 & 0.0544 & 0.0417 & 0.0261 & 0.0665 & 0.0408 \\
\hline \multirow[t]{2}{*}{ ROAE } & Coef. & 0.0067 & -0.0080 & $-0.0305^{* * *} *$ & -0.0043 & 0.0006 & $0.0231 *$ \\
\hline & SE & 0.0076 & 0.0062 & 0.0102 & 0.0059 & 0.0005 & 0.0132 \\
\hline \multirow[t]{2}{*}{ Government $>50 \%$} & Coef. & -0.0519 & $0.6674 * *$ & 0.0771 & -0.1447 & 1.0133 & $2.5137 * *$ \\
\hline & SE & 0.3224 & 0.2864 & 0.0704 & 0.1345 & 0.7579 & 1.2126 \\
\hline \multirow[t]{2}{*}{ Government $<50 \%$} & Coef. & & $0.3892 *$ & & & 0.1153 & \\
\hline & SE & & 0.1986 & & & 0.3090 & \\
\hline \multirow[t]{2}{*}{ GDP growth rate } & Coef. & $0.0802 *$ & -0.0052 & -0.0027 & $0.1647 * * *$ & 0.0397 & -0.0179 \\
\hline & SE & 0.0384 & 0.0488 & 0.0064 & 0.0454 & 0.0629 & 0.0193 \\
\hline \multirow[t]{2}{*}{ Unemployment rate } & Coef. & -0.0370 & 0.0418 & $-0.1252^{* * *} *$ & -0.6786 & 0.0514 & -0.0506 \\
\hline & SE & 0.2925 & 0.1415 & 0.0471 & 0.5783 & 0.0558 & 0.0894 \\
\hline \multirow[t]{2}{*}{ Inflation rate } & Coef. & & 0.0480 & -0.0193 & 0.1202 & 0.0276 & 0.0516 \\
\hline & SE & & 0.1405 & 0.0419 & 0.0627 & 0.0786 & 0.0698 \\
\hline \multirow[t]{2}{*}{ Central bank rate } & Coef. & $-0.2918 * * *$ & 0.0029 & -0.0065 & -0.2245 & 0.1218 & -0.0217 \\
\hline & SE & 0.0673 & 0.1177 & 0.0243 & 0.1895 & 0.2289 & 0.0635 \\
\hline
\end{tabular}

Notes: $* * *, * *$ and $*$ denote significance at the $1 \%, 5 \%$ and $10 \%$ level, respectively. 